modest proposal may require member states to enter into binding agreements on avoiding beggar-thy-neighbour tax/wage policies. Arguably, all countries might also agree on broad guidelines for national wage policies (e.g. stipulating that wages should be allowed to rise in line with labour productivity - no more, but also no less). Agreeing on such guidelines means more policy coordination at the EU level. A labour-productivity driven wage policy, with the individual countries' average nominal wages increasing in line with average labour productivity (augmented by a common ECB target pertaining to inflation) would result in national inflation rates approximating the common target inflation rate. Importantly, such a policy would help narrow divergences within the euro area. It would then be possible to run the one size fits all monetary policy, without provoking centrifugal forces within the euro area.

Finally, other possibilities exist for accelerating growth in the EU - which can also reduce the centrifugal tensions. But the realisation of these possibilities would require a radical revision of the unreasonable provisions of the Stability and Growth Pact. This topic remains to be properly addressed.

\title{
References
}

European Central Bank (20IO): Euro area fiscal policy and the crisis, Occasional Paper Series, No. I09, April.

European Commission (20IOa): Surveillance of Intra-Euro-Area competitiveness and imbalances, in: European Economy, I/20Io.

European Commission (2OIOb): European economic forecast - spring 2010 (provisional version), in: European Economy, 2/2010.

\section{Evolutionary Institutionalism. Sources, history and contemporary relevance of The Association for Evolutionary Economics - AFEE Wolfram Elsner*}

\section{Some prehistory - Veblen's foundations and the rupward decades}

Evolutionary-institutional economics is more than IIo years old. It started with Thorstein $B$. Veblen's fundamental criticism, put forward in a bulk of papers and books from the I88os on, of the then just-established neo-classical economic mainstream. Veblen had worked empirically, and established on theoretical, methodological, and philosophical levels a new type of economics. He pointed out the simplistic, equilibrium-oriented, over-optim(al) istic, and teleological view that had emerged from the Scottish Enlightenment school to the

* University of Bremen, iino - Institute of Institutional and Innovation Economics.

(C) INTERVENTION 8 (I), 2OII, 29-4I 
classical economists from Adam Smith on ('the fable of the beesı, the snatural pricer and invisible hand ‘ metaphors, etc.), even though the Scottish Enlightenment had developed an early understanding of what today would be termed 'complex emergencer, already pointing beyond a simple mechanical analogy. In his view, their naïve teleological inclinations had paved the way for the overtly simplistic, autistic, rigid, equilibrium- and optimality-based neoclassical modelling of a 'perfect-market e economy which he considered straightforwardly outmoded, ideological, counter-productive, and dangerous.

Complex biological evolution theory after Darwin, along with new developments in physics, human biology, anthropology, and psychology made Veblen elaborate that also modern social sciences must be evolutionary in the phylogenetic (population-based and diversification centred) sense, thereby comprehending economies sopen to (and 'markets economies in fact exploiting) both the societal and natural environments, thus being also complex and path-dependent. He considered real-world economic theorizing non-teleological, non->optimal , and open-ended. After years of empirical industrial research, he came to ask, in his famous 1898 article Why is economics not an evolutionary science? - a similar turn that also Alfred Marshall had made after his empirical studies of industries, prices, agglomerations, etc., who also came to state the Mekkar of economics to be in biology. But Marshall got stuck with this theoretical change halfway (typically in an ontogenetic, i.e., a problematic organicist metaphor).

Veblen considered also Marx to remain partly in the classical steleology،. But on the other hand, he had a deep and fruitful discourse with Marxism with which he largely shared the analysis of classes and views on the untenability of capitalism. Marx, in turn, had recognized the historical progress of the Darwinian revolution, although only in his late days - after having detached the simplistic and Panglossian references Darwin himself had made to the early Scottish economists and to Malthus, where evolution was always somehow ameliorating, and after having separated Darwin from the reduced, biologistic and ssocioDarwinistic interpretation. After Marx' death, Engels became even more clear about the historical progress made also for the social sciences through a properly understood, complex Darwinian evolutionary process. Thus, Marx and Marxism have become an important and continuing source for most evolutionary institutionalists from Veblen's days onwards.

While Veblen still somehow saw too much steleology in Marx' historical philosophy, he sympathised with the German Historical School (and the English Historicists) and participated in the ‘big methodological debates of the time (`Methodenstreit`). But he criticised also the historical schools, namely as perceiving history and process in under-theorized ways. Nevertheless, there emerged some relations between American institutionalism and the German historical school, with Richard T. Ely, the founder of American agricultural and land economics, who had studied with G. Schmoller, being considered the most prominent case here.

Veblen's Theory of the Leisure Class (I899) made him famous to a large audience. He analyzed predatory histories of socio-economies, based on emulation and invidious distinctions, and their imbeciles institutions, oppressing the other motivational potentialities of humankind, particularly the instinct of workmanship, the sparental bent 
Institutions are (mostly informal) social rules and values emerging and changing in complex, evolutionary processes including cumulative causation through learning, socialisation, imitation, formal enforcement and violence - thus sevolutionary institutionalism .

In those invidious, emulative and predatory societies - and the capitalist smarket economy with its imperialist reach does constitute predatory societies - the ceremonial, i.e., power- and status-based, motivations, values, and behaviours typically encapsulate any technological and scientific progress, which otherwise could be fully used for instrumental problem-solving.

After analysing ceremonial consumption, fashion, and education styles, modes of government and imperialism in the Theory of the Leisure Class, Veblen later proceeded, in his Theory of the Business Enterprise (1904), to focus more on ceremonial, particularly pecuniary business, which sabotages , industry`, industriousness, professionalism, instrumentalism, production and welfare, in favour of redistribution into the speculators' pockets of the wealth produced. With this analysis Veblen was absolutely farsighted, modern, and contemporary, in the face of current pecuniarily dominated and speculative casino capitalism.

With the conceptions of technologyvs. institutions, and instrumentalism vs. ceremonialism, Veblen not only founded what he coined evolutionary economics and what later was also termed institutional economics (and particularly American Institutionalism). He also largely founded what nowadays has merged into anti-mainstream, heterodox complexity economics. But he also shaped the core discussions over the next decades within evolutionary-institutional(ist) economics on its empirical and theoretical research programme: the relation between technological change and institutions. Nowadays it is largely agreed in evolutionaryinstitutional ranks that imbecile`, ceremonially dominated, and particularly pecuniary institutions can, and increasingly do, shape technology and prevent, impede, sabotage, deteriorate, or pervert technological opportunities for social or ecological instrumental problem-solving. Thus, there is no independent, value-free stechnology‘. However, basically, new technological knowledge (an sincrease in the social knowledge fund ) may change institutions sometimes even in a progressive sense. But it is also widely agreed that (informal) institutions not only are salways there, but also indispensable to coordinate agents in any decentralised, individualistic, complex situations with typical social-dilemma, or collectivegood, problem structures. And neo-liberal (in fact, neither `neo nor >liberal $)$ ), de-regulated 'market ‘ capitalism is overly decentralised, overly complex, overly uncertain, and overly turbulent, while real problem-solving in a 'negotiated economy`, would require both broader collective and more long-run rationalities.

Institutions, thus, are emergent from complex evolutionary process as complexityreducing, learned and habituated, anti-hyper-rational, coordinating collective solutions (institutional emergence), furthermore, they are ever-changing in ongoing evolution (institutional change), and, finally, as whole institutional arrangements, they are responsible for comparative aggregate outcomes (comparative institutions). This defines broad areas of the evolutionary-institutionalist research agenda.

Veblen in this way had set the scene for modern evolutionary, institutional economics, and complexity, critical to capitalist reality. He was the founding father of institutionalist 
economics, which was a serious challenge for the neoclassical mainstream during the I920s and I930s (and its misperceived physical analogies of economics as a 'pure sciencer and social mechanics`). In fact, Institutionalism was the dominating economic perspective in the USA in that time. Allegedly, Veblen was even offered the presidency of the American Economic Association (AEA) in the mid-twenties, when the association in fact was already neoclassically dominated, which he refused - perhaps because he was considering the fact that he never was offered a tenured position in his academic career, after having taught at many prominent universities.

Veblen died in 1929, after having published most important papers and books, among them some important applied writings on the post-WW-I international order, with thoughts similar to those of Keynes at that time.

\section{More prehistory of AFEE - Commons, Mitchell, Ayres, and others}

But American institutionalist economics is also commonly associated with John R. Commons, the founder of the ' Wisconsin Schook of Institutionalism, and Wesley C. Mitchell, the most famous empirical business researcher of his time from Columbia University, NYC, the founding father of American empirical business-cycle and macro research.

Commons had become famous through his history of American labour, and gained renown as a leading institutionalist through his Legal Foundations of Capitalism (1924), his Institutional Economics (1934, 2 Vols.) and later his Economics of Collective Action (1950), where he focussed on institutions less as 'habits of thought (Veblen) but as control of individual action in favour of collective action, which appears extremely modern if, for instance, considered in a game-theoretic social-dilemma, sunintended-consequences`, and 'fallacyof-aggregation ‘ perspective. He also can be considered the real founder of (non-marginal, though) transaction (cost) economics (later occupied by Coasian economics), and of law and economics (later occupied by neoliberal hardcore neoclassicists of the Chicago school). Coming from social, labour, and civil law, his focus was on comparative social interests and values, on the rational and transparent negotiation of prices, on socially reasonable values and on working rules, a transparent, socially sustainable negotiated welfare economy where futurity and consistent mutual expectations would loom large (again, extremely modern, e.g., in a game-theoretic perspective). His school gained a considerable influence in the I920s and 1930 in the construction of the US-welfare state that had a time window to emerge in the Roosevelt area, on both state and federal levels (a few north-eastern and north-western states in the US still have some of those welfare-state laws and some related capacities today).

Against this background, the later Association for Evolutionary Economics - AFEE has launched an annual Veblen-Commons Award from its first days on as its most highly recognized award.

Mitchell had developed his large-scale empirical research along the lines of Veblenian themes from the very beginning, focussing on the capitalist anarchy of production, its instability, over-turbulence, and irrationalities under ceremonial (pecuniary) dominance. Nevertheless (or because of this), he grew into the founder and builder of the US national 
economic statistics system and empirical business cycle research (with the statistical offices, the National Bureau of Economic Research, NBER, founded by him, the Council of Economic Advisers, etc.). Many institutionalists joined Mitchell in focussing on empirical-statistical work, while maintaining a strong evolutionary-institutional theoretical focus (among them A.F. Burns, A. Lowe and many others). This statistical body was later publicly considered paving the way to communism by a movie actor in the White House (Nixon).

In the fields of industrial, anti-trust, business, and financial markets statistical analysis and related policies, two further prominent institutionalists dominated the scene from the I930s through the I950s: Gardiner C. Means and Adolf A. Berle who could build on Veblen's analysis of absentee ownership and analysed the capital and power structures, and behaviour, in the then already full-fledged corporate capitalism, a most important field of institutionalist critique and theory-building until today (see, e.g., John Munkirs' works on the centralized private sector planning, 1985, and Bill Dugger's Corporate Hegemony, 1989).

But from the late 1930 on, after the Paretian revolution in neoclassicism, after the Keynesian revolution in macroeconomics (with its implicit anti-neoclassical microeconomics), and after the establishment of the American war and armaments economy, evolutionary Institutionalism lost ground both in politics/public administration and in economic science. The dominating institutionalist of that period was Clarence E. Ayres who further developed institutional theory, methodology, philosophy, and policy/democracy conceptions into a fruitful combination with American pragmatist (instrumentalist) philosophy, represented by Charles S. Pierce and John Dewey. He contributed considerably to clarifying the discussion on stechnology< vs. sinstitutions that still was somewhat skewed by Veblen's bias against institutions workers and engineers as the revolutionary class (see above for the general post-Ayresian consensus on stechnology vs. institutions`). The Theory of Economic Progress (1944) was his opus magnum in that respect.

AFEE later also launched an annual Clarence E. Ayres Visiting Scholar Award for a foreign scholar from its beginning. ${ }^{\mathrm{I}}$

\section{The downswing years of evolutionary Institutionalism, single institutionalist stars, and allies of Institutionalism}

The Keynesian post-WW-II and bastard `neoclassical-synthesis` years, lasting until the late I960s, saw a strong 'down to mathematical rigor compared to neoclassical economics and the then new opportunities for Keynesian macro-modelling and empirical macro research. This has changed, with new system-dynamic modelling, evolutionary-institutional interpretations of game theory, dynamic graph and network analyses, or complex computer simulations, related to new tools developed within Institutionalism such as the Social Fabric Matrix approach, SFM-A; see below). Its big local centres at universities, such as the Wisconsin, Michigan, and Texas 
Schools, became more or less eliminated, and they were at least ignored, if not fought (silently or overtly) by the neoclassical mainstream. As one recent source puts ist:

"The methodological battle [...] had robbed the Institutionalists of their early strongholds, the Johns Hopkins University and the American Economic Association (AEA). The growing sway of the Marginalist Revolution over American academia particularly at the hands of Fisher at Yale, Taussig at Harvard and Knight at Chicago, gnawed further away at the Institutionalists' position « (American Institutional School, cepa/newschool website 2009).

Also, there was virtually no heterodox post-Keynesian school (or organized groups) and no associated Marxian radical economics yet, and also Schumpeterian heterodoxy was still far from being organised as a group. No conditions for synergies among heterodox streams existed yet.

Thus, the late I940s through the mid-I96os were the decades of institutionalist decline as a group, organized earlier through its different university schools. Nevertheless, some big names still were there and some new ones came up who at least considered themselves in the institutionalist tradition. But they were, then, mostly isolated one-person islands: among them were - beyond those already mentioned - Walton Hamilton, John M. Clark, Kenneth Boulding, and most prominently John K. Galbraith, in Europe: Gunnar Myrdal and Karl W. Kapp, later Nicolas Georgescu-Roegen. Further known 'heterodox ‘ economists (the term sheterodox', of course, was not in use then) who did not directly contribute to the maintenance of an institutionalist group with an identifiable, coherent research programme, but who were part of its larger discourse, were Joan Robinson, and Adolf Lowe, later Lowe's student at the New School (NYC), Robert Heilbroner, also largely Paul Sweezy, Hyman Minsky, Howard Sherman, Daniel Bromley, or Richard Nelson, to mention but a few and rather diverse economists. We are talking here about a time-span as large as the I950s through the I980s. ${ }^{2}$

But known, confessing institutionalists, still working closely on the institutionalist research agenda, did also continue to exist from the I950s onwards. Among them were Joseph Dorfman, Allan Gruchy, John F. Foster, David Hamilton, Louis F. Junker, and Wendell Gordon. But this group was becoming smaller and more isolated, at fewer universities.

Places with institutionalist economists and rallies in discourse ‘ were the New School for Social Research, NYC, (Lowe, Heilbroner), places at different Colorado Universities (Denver and Colorado State Universities), Portland State, OR (H. Vatter, R. Brinkmann), California State universities (Fresno, Sacramento, Davis, with M. Tool, P. Bush, J. Cypher, and others), University of Utah at Salt Lake City (E.K. Hunt, H. Sherman, and others), Michigan State (W. Samuels), Notre Dame, IN (P. Mirowski and others), some few in the South East (University of TN, Knoxville, with A Mayhew, W. Neale, H. Jensen, and others), Lincoln,

2 Note that also the field of business studies became affected by complexity economics, particularly evolutionary-institutionalist perspectives, as is reflected nowadays in so-called learning and resourcebased approaches to the theory of the firm. An early representative here was Edith Penrose's The Theory of the Growth of the Firm (1959). The major competing heterodox perspective in this area, however, is neo-Schumpeterian economics. 
NE (F.G. Hayden, A.M. May), some in the South West: New Mexico State University (J. Peach, R. Adkisson), and Texan universities (e.g., Austin: James Galbraith). Later arrivals include: University of Missouri at Kansas City (perhaps the strongest institutionalist centre currently, with J. Sturgeon, R. Wray, M. Forstater, F. Lee, S. Bell-Kelton, W. Black, J. Henry, J. Webb, J. Kregel, and others), UMass at Amherst, Tufts University, Bard College (Levy Institute), Dickinson College and some few others. Again, this covers decades and refers in varying degrees to different periods between the I960s and now. And this list is far from being complete.

\section{Finally, an organization on its own}

After all, while most of the group >confessing interest in the Veblenian-Ayresian legacy regularly went to the annual meetings of the $A E A$, they were generally ignored, isolated, or disparaged there. Allan Gruchy, finally, took the initiative to form informal annual group meetings on these occasions from the late I950s onwards, and in the end, the group founded AFEE in 1965. American Institutionalism had an association of its own for the first time, 60 years after Veblen's establishment of the foundations of evolutionary-institutional economics. Two years later, they established their Journal of Economic Issues (JEI), finally, taken over by a sympathetic professional publisher recently, the major institutionalist/heterodox publishing house M.E. Sharpe. (More recently, AFEEmail, has become a lively and important media of scholarly, higher-education, and general political ideas and material exchange.)

AFEE introduces itself in the following way (on its website, following its founding declaration):

"The Association for Evolutionary Economics (AFEE) is an international organization of economists and other social scientists devoted to analysis of economics as evolving, socially constructed and politically governed systems. [...]

The intellectual heritage of AFEE is that of the Original Institutional Economics (OIE) created and developed by early twentieth-century economists such as Thorstein Veblen, John R. Commons, and Wesley Mitchell. Over recent decades, this legacy has evolved to address such contemporary issues as:

- The role of diverse cultures in economic performance.

- Domestic and international inequalities of income.

- The roles of social, economic and political power in shaping economic outcomes.

- Globalization and the increasing weight of multinational corporations in the international economy.

- The need for expanding use of modern technologies to relieve want.

- The urgent need for awareness of the impact of new technology on the biosphere.

- The ways in which economic thought is affected by and affects always changing economies $[\ldots] \lll$

Having an own organization allows making prominent institutionalists visible as both presidents and award recipients. In fact, there was a pent-up stockpile of merited and profiled 
institutionalists in the I960s and I970s who had fought those early and continuing fights within the AEA and at their annual conferences for many years: C. Ayres, J. Gambs, A. Gruchy, J. Dorfman, B. Seligman, D. Fusfeld, D. Hamilton, H. Trebing, S. Melman, D. Dillard, J. Street, W. Gordon, M. Lower, and D. James were among the older group of institutionalists having worked from the I940s to the I970s, now to become AFEE presidents in a row, and J. Munkirs, P. Bush, M. Tool, J. Sturgeon, J. Adams, G. Hayden, V. Briggs, B. Dugger, R. Stanfield, Y. Ramstad, J. Swaney, J. Peach, W. Waller, C. Clark, and G. Atkinson were among the younger generation of followers, often the former group's students, grown up with the association existing already, to become presidents from the I980 to the 2000 . More recently, even some foreign institutionalists became presidents, such as J. Groenewegen (NL), G. Hodgson (UK), and M. Rutherford (CAN). Currently, James K. Galbraith is President-Elect for the period 2OII-I2 and will be President in 20I2-20I3.

Similarly, the stockpile of deserved heterodox veteran fighters to be honoured and awarded with the Veblen-Commons Award was equally pressing in the early years of the association. That stockpile had been 'worked off^ (through many double awards per year in the I960s and I970s) by the mid-I980s. From the inner ' group of then younger institutionalists, A. Mayhew, F.G. Hayden, W. Dugger, J.R. Stanfield, R. Tilman, P.D. Bush, and G. Atkinson were up for the award in the 2000 .

But also, prominent sexternal institutionalists, those lone stars mentioned, who were no `AFEE-workers but always had been allies and now were important for the visibility of AFEE, could be included: G. Myrdal, J.K. Galbraith, A. Lowe, R. Heilbroner, H. Minsky, S. Melman, P. Sweezy, H. Sherman, and R. Nelson.

\section{Movement, differentiation, and heterodox synergies}

The late sixties were the times of movement and upsurge of sheterodox thinking which generated synergies for all: Marxists and 'Radicals founded URPE, the Union for Radical Political Economy, some socio-economists (with A. Etzioni leading) later founded the Society for the Advancement of Socio-Economics (SASE), while older groups, originally motivated by ethical and even religious programmes, such as ASE, the Association for Social Economics, revived. The Post-Keynesians followed later with own organised groups, particularly the Post-Keynesian Economics Study Group (PKESG). In the I990s and 2000 s more heterodox associations followed, including the Association of Heterodox Economics (AHE), the International Association for Feminist Economics (IAFFE), the International Network for Economic Method (INEM), the Economists for Peace and Security (EPS), and, more recently, the Research Network Macroeconomics and Macroeconomic Policies (FMM). They all had their upswings together, and AFEE reached some 700 members in the late I980s, its JEI running well, being considerably well-ranked in many journals ranking lists, and widely appreciated (and measured by cross-citations) as one of the leading heterodox journals. At the AEA-dominated annual meetings the American core groups (ASE, AFEE, URPE, ...) have developed strong collaboration. 
A number of institutionalists strongly committed to the Veblenian heritage and research agenda soon considered AFEE too broad to allow for a degree of focus in the discussion they thought to be needed. They founded the Association for Institutional Thought (AFIT) in I979, a smaller group, probably below Ioo members, that, however, in the end has developed a close cooperation and division of labour with AFEE. Double membership of AFIT members in both associations thus is common, and, considering publication, after a short-run experiment with their own journal in the early eighties, they have focussed on the JEI. Nowadays, AFIT serves the annual meetings of the WSSA, Western Social Science Associations in Spring, while AFEE meets at the AEA-dominated Allied Social Science Associations (ASSA) meetings in early January. ASE and URPE, in turn, play a considerable role also at the annual meetings of the Eastern Economic Association (EEA) regulary taking place in February or March.

While the revival of ASSA (formally established already in the late I930s) was basically a great success for the many heterodox and specialised associations after the years of 'motion in the late I960s and I970s, they still all have trouble with the organisational dominance of the AEA within ASSA which strives to reduce the slots for heterodox associations' sessions at the annual conferences (allegedly based on their smaller audiences, which, however, does not appear to be the case). The heterodox associations already mentioned, but also ACES (comparative studies), SABE (behavioural economics), and others collaborate to fight this policy and at the same time often demonstrate strength through spectacular joint sessions. But there have even been joint AFEE/AEA, ASE/AEA, and URPE/AEA sessions, with people like Douglass North, Richard Nelson, or Oliver Williamson sometimes building bridges and appearing at joint panels.

Nevertheless, the conditions for institutionalists and other heterodoxers are basically more favourable in the frame of WSSA and its Eastern counterpart, the EEA, than in ASSA, where, as indicated, there has been some disquiet in recent years on the issue of the policy of AEA vis-à-vis the heterodox associations.

\section{Internationalization of evolutionary-institutionalist heterodoxy}

In the early I980s, leading AFEE members like M.R. Tool and P.D. Bush made efforts to contact European heterodox economists and finally helped launch the European sister organization EAEPE, European Association for Evolutionary Political Economy in 1988 that quickly gained some 500 members and has its own journal now in its $6^{\text {th }}$ year (Journal of Institutional Economics, JoIE). But also a Japanese evolutionary-institutionalist association, the Japanese Association for Evolutionary Economics (JAFEE) with a considerable level of activities and its journal Evolutionary and Institutional Economics Review, emerged, as well as a Chinese evolutionary economic association, and heterodox and institutionalist associations in Australia, Brazil, the UK, France, and the Netherlands.

Today, Institutionalism is international and so is the membership of AFEE. Among its active international members are B. Buergenmeier, K. Dopfer $(\mathrm{CH})$, W. Blass, H. Hanappi (A), H.-P. Brunner, C. Cordes, W. Elsner, C. Herrmann-Pillath, W. Kerber, H. Peukert, U. Witt(G), J. Groenewegen, W. Dolfsma, I.v. Staveren, E.-M. Sent, A.H. Spithoven (NL), G. Hodgson, 
P. Arestis, R. Mansell, R. McMaster, H.P. Young (UK), M. Rutherford, J. Cornwall, M. Lavoie (CAN), D. Dequech (Brazil), P. Petit, R. Delorme, O Brette, I. Peaucelle (F), L. Mampaey (B), W. Melody, K. Nielsen (DK), P.A. O'Hara, J. Potts (AUS), Y.E. Oezveren (Turkey), P. Ramazzotti (I), to mention just a few.

Valuable sources for a more detailed international overview of both AFEE and organized heterodoxy in general are not only the AFEE website but also the website of the International Confederation of Associations for Pluralism in Economics - ICAPE, the Heterodox Economics Newsletter (HEN), the Post-Autistic Economics journal and its PAEcon website (now: realworld economics review), and the Heterodox Directory website run by F.S. Lee at UMKC. They all include information on departments and their educational programmes, on journals, and associations.

The discussion among all heterodoxies has become considerably intense and fruitful, and in many respects unexpectedly converging. For a short final illustration of potential converging themes, see the following Figure.

\section{Some prospects}

We have analyzed elsewhere that, and to what extent, heterodoxy in a wide sense - but not least in the evolutionary-institutionalist sense - has gained ground, and in fact has gained the forehand in providing and defining the most advanced and demanding research questions and agenda for economics in the last, say, three decades, and that heterodoxies have even dominated discussions recently in most prominent print media on the global financial and economic crisis (see Elsner/Lee 20IOa and 20Iob). For Institutionalism in particular, we may consider the examples of P.D. Bush's Theory of Institutional Change (Bush 1987) or F.G. Hayden's SFM-A (Hayden 2006, Natarajan/Elsner/Fullwiler [eds.] 2009), which have elaborated Institutionalism's logical structures up to a point where properly interpreted and applied formal analyses like econometrics, system dynamics, graph theory, network analysis, game theory, and computer simulation of complex models now can be fruitfully applied to the institutionalist research agenda.

Many fields, especially, in our case, Coase-Williamsonian New Institutional Economics (NIE) vs. Veblenian-Evolutionary-Complex Original Institutional Economics (OIE), are displaying complex simultaneous motions of theoretical convergence and continuing paradigmatic distinction. We have also argued elsewhere that this soffensiver position in advanced research (put most simple: complexity vs. simplistic equilibrium economics) does not have any positive impact on the positions of heterodoxies in the areas of mass teaching and textbook production (and sales), the businesses of public advice, fund raising, and, particularly, of personnel recruitment (see, e.g., Elsner 2008).

On the contrary, we perceive some orthodox counterattack, not so much in research, where heterodox and complex issues appear to be continuously more attractive while the neoclassical research agenda as such more or less is exhausted - but in the mass media and, in particular, in the field of academic teaching, which remains unswayed by the fundamental global crises, and in academic recruitment, where the new ranking games are set up to generate 


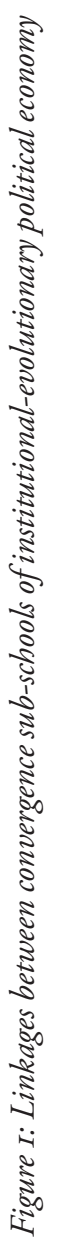

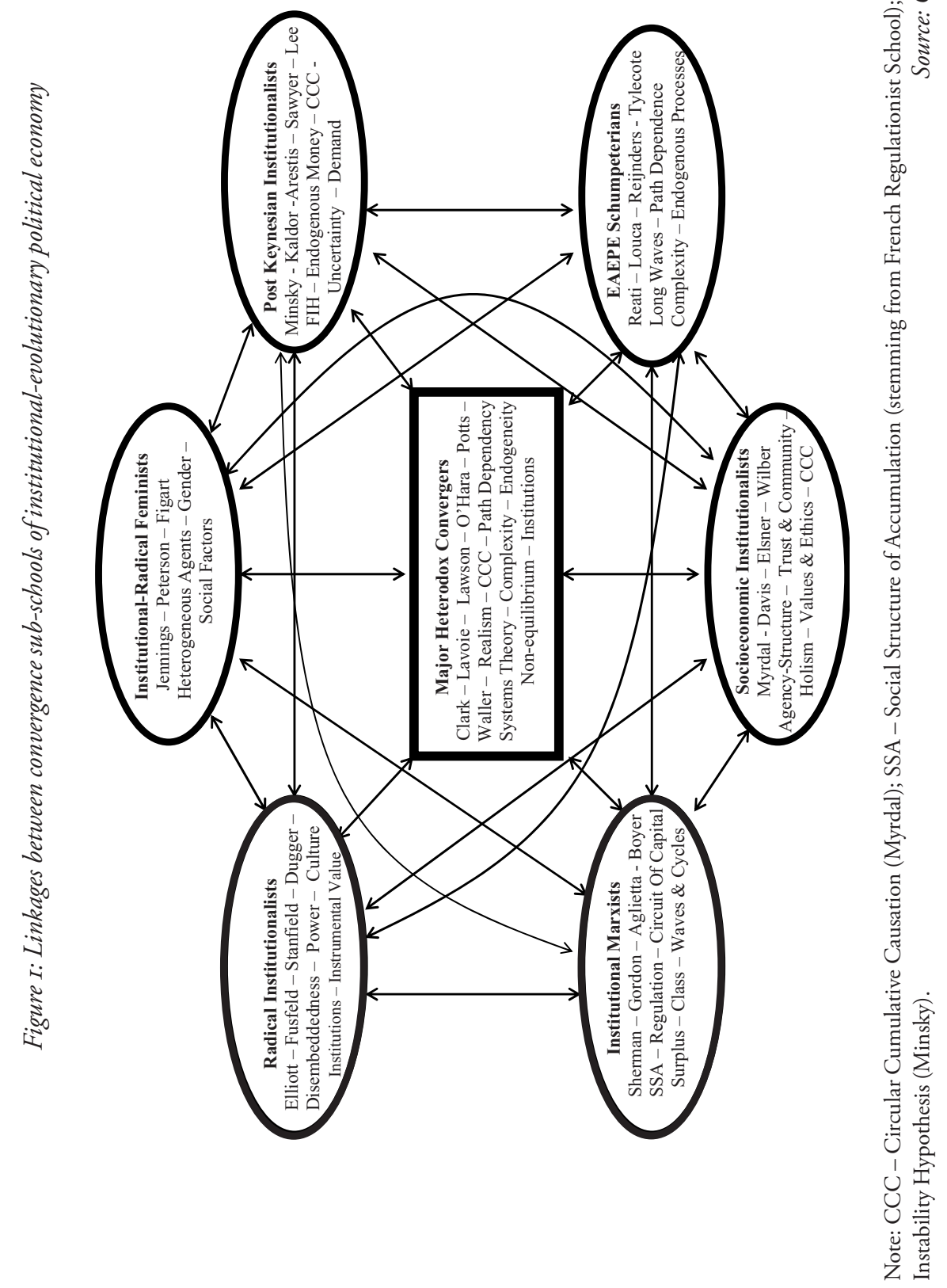

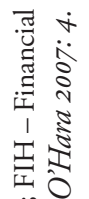


a complete racademic cleansing . So, none of the beliefs heterodox economists ever stood up for are ssafer, once and for all gained territory or have a guaranteed existence. On the contrary, they are under attack by a predominant mainstream, and in an unequal competition so. Economic heterodoxies in academia need to be defended today more strongly in order to survive.

\section{References and further readings}

American Institutional School - A survey of this school, itself a branch of the historical schools, URL: cepa.newschool.edu/het/schools/institut.htm, accessed September 3, 2010.

Ayres, C.E. (1944): The Theory of Economic Progress, New York: Farrar and Rinehart.

Bush, P.D. (1987): The theory of institutional change, in: Journal of Economic Issues, 2I(3), I075-II6.

Caldari, K. (20I0): Institutional economics and the concept of equilibrium, in: Journal of Post Keynesian Economics, 32(4), 60I-22.

Commons, J.R. (1990): Institutional Economics. Its Place in Political Economy, 2 Vols., New Brunswick, NJ, London: Transaction Publishers [New York: Macmillan, 1934].

Dugger, W.M. (1992): Underground Economics. A Decade of Institutionalist Dissent, Armonk/ London: M.E. Sharpe.

Elsner, W. (1986): Ökonomische Institutionenanalyse, Berlin: Duncker und Humblot.

Elsner, W. (1987): Institutionen und ökonomische Institutionentheorie. Begriffe, Fragestellungen, theoriegeschichtliche Ansätze, in: Wirtschaftswissenschaftliches Studium - WiSt, I6(I), 5-I4.

Elsner, W. (2008): Market and state, in: O’Hara, P.A. (ed.), International Encyclopedia of Public Policy, Global Governance and Development, Vol. III: Public Policy, GPERU: Perth, URL: http://pohara.homestead.com/Encyclopedia/Volume-3.pdf, 370-89.

Elsner, W., Lee, F. (20IOa): Assessing economic research and the future of heterodox economics. Failures and alternatives of journals, departments, and scholars rankings, in: Intervention. European Journal of Economics and Economic Policies, 7(I), 3I-42.

Elsner, W., Lee, F.S., (20Iob): Editors' introduction to 'Evaluating economic research in a contested discipline. Rankings, pluralism, and the future of heterodox economics', Studies in economic reform and social justice, Wiley-Blackwell Publ., Special issue of the American Journal of Economics and Sociology, 69(5), I-I2.

Gruchy, A.G. (1972): Contemporary Economic Thought. The Contribution of Neo-Institutional Economics, Clifton, NJ: A.M. Kelley.

Hayden, F.G. (2006): Policymaking for a Good Society. The Social Fabric Matrix Approach to Policy Analysis and Program Evaluation, New York: Springer.

Hodgson, G.M. (2006): Economics in the Shadows of Darwin and Marx. Essays on Institutional and Evolutionary Themes, Cheltenham, UK/Northampton, MA, USA: Edward Elgar.

Hodgson, G.M. (1998): The approach of institutional economics, in: Journal of Economic Literature, 36(I), 166-92.

Hodgson, G.M., Samuels, W.J., Tool, M.R. (eds.) (1994): The Elgar Companion to Institutional and Evolutionary Economics, 2 Vols., Aldershot, UK: Edward Elgar.

Institutional economics, Wikipedia, accessed June 22, 2010. 
Mitchell, W.C, Dorfman, J. (eds.) (1969): Types of Economic Theory: From Mercantilism to Institutionalism, Boston: Harvard University Press.

Munkirs, J.R. (1985): The Transformation of American Capitalism: From Competitive Market Structures to Centralized Private Sector Planning, Armonk/NY/London: M.E. Sharpe.

Natarajan, T., Elsner, W., Fullwiler, S. (eds.) (2009): Institutional Analysis and Praxis. The Social Fabric Matrix Approach, New York: Springer.

Neale, W.C. (1994): Institutions, in: The Elgar Companion to Institutional and Evolutionary Economics, Hodgson, G.M., Samuels, W.J. Tool, M.R. (eds.), Aldershot/Hants, UK/ Brookfield, VT, USA: Edward Elgar, Vol. I, 402-6.

O'Hara, P.A. (2000): Marx, Veblen, and Contemporary Institutional Political Economy. Principles and Unstable Dynamics of Capitalism, Cheltenham, UK/Northampton, MA, USA: Edward Elgar.

O'Hara, P.A. (2007): Principles of institutional-evolutionary political economy - Converging themes from the schools of heterodoxy, in: Journal of Economic Issues, $4 \mathrm{I}(\mathrm{I}), \mathrm{I}-42$.

Reuter, N. (1994): Der Institutionalismus. Geschichte und Theorie der evolutionären Ökonomie, Marburg: Metropolis.

Rutherford, M. (2011): The Institutionalist Movement in American Economics, 19I8-1947: Science and Social Control, Cambridge, UK: Cambridge University Press.

Samuels, W.J. (2008): Institutional economics, in: Durlauf, S.N. and Blume, L.E. (eds.), The New Palgrave Dictionary of Economics, New York: Macmillan, $2^{\text {nd }} \mathrm{ed}$.

Tool, M.R. (1979): The Discretionary Economy: A Normative Theory of Political Economy, Santa Monica, CA: Goodyear Publishing.

Veblen, T. (1979): The Theory of the Leisure Class, [1899], New York, USA/Harmondsworth, UK: Penguin Books. 
